The Geneva Papers on Risk and Insurance, 17 (No. 63, April 1992), 200-207

\title{
Insurance Activities in OECD
}

by André Laboul*

\section{The Organisation for Economic Co-operation and Development (OECD)}

The Organisation for Economic Co-operation and Development (OECD) is an intergovernmental organisation with a current membership of 24 countries, all of which share a number of basic values - pluralistic democracy and market-oriented economies, in particular. These countries are : in North America - the United States and Canada; in Europe - the twelve EEC Member States (Belgium, Denmark, France, Germany, Greece, Ireland, Italy, Luxembourg, the Netherlands, Portugal, Spain and the United Kingdom), the EFTA countries (Austria, Finland, Iceland, Norway, Sweden and Switzerland) and Turkey; and, in the Pacific area - Australia, Japan and New Zealand. The OECD was founded in $1961^{1}$ with the basic aim to promote polices designed to achieve the highest sustainable economic growth and employment and a rising standard of living in Member countries, while maintaining financial stability, and thus to contribute to the development of the world economy; to contribute to sound economic expansion in Member as well as non-member countries in the process of economic development; and to contribute to the expansion of world trade on a multilateral, non-discriminatory basis in accordance with international obligations (Article 1 of the Convention).

A number of specialised bodies (committees and working parties in particular) were set up and entrusted with the task of working towards these objectives. These bodies which deal with a wide range of sectoral and cross-sectoral issues - are made up of senior government representatives. They are served by an international secretariat.

The supreme authority of the Organisation is the Council, which consists of the Heads of Member countries' Permanent Delegations to the OECD. Decisions (legally binding on Member countries) and Recommendations (expressions of political will) are adopted on the basis of consensus; the OECD is not a supranational organisation but a forum for discussion where governments exchange views and experience, assess political, economic, financial and social changes, and try to cstablish common positions.

* OECD, Directorate for Financial, Fiscal and Enterprise Affairs. The views expressed herein are those of the author and not necessarily those of the OECD.

1 OECD was founded in September 1961, succeeding the OEEC (Organisation for European Economic Co-operation ) - the Organisation created in April 1948 to administer the Marshall Plan. 


\section{The OECD Insurance Committee}

OECD's Member countries account for about 90 per cent of world insurance business, all branches combined. This fact, together with the importance of the insurance industry within the economic, social and financial system of Member countries, were without doubt major reasons for the creation of a specialised Committee dealing with insurance matters. Unlike most other OECD committees, the Insurance Committee, which was set up back in 1961, comprises not only government representatives from the relevant ministries and/or the insurance supervisory authorities but also representatives of professional associations of insurers. Representatives of a number of other international organisations also take an active part in the work of the Committee, i.e. the European Economic Community, the European Free Trade Association and the European Insurance Committee. The mandate of the Insurance Committee is a very broad one:

- The Insurance Committee (hereinafter called "The Committee") shall have the task of further developing and strengthening co-operation among Member countries in the field of insurance;

- The Committee shall undertake any studies necessary to achieve a better understanding of the policies of Member countries in regard to insurance and of the economic importance of and developments in the insurance sector in Member countries;

- The Committee shall be responsible in particular for pursuing, in co-operation with the Committee on Capital Movements and Invisible Transactions, efforts to achieve greater freedom in the field of insurance and for helping that Committee on any matter concerning the application of provisions of the Code of Liberalisation of Current Invisible Operations relating to insurance;

- The Committee shall keep itself informed of the activities carried out in other international bodies in regard to insurance, shall provide a forum for consultations between Member countries to enable them to exchange views on issues raised in such bodies, and shall carry out work enabling a better understanding to be reached of international insurance issues;

- The Committee shall be responsible for monitoring and promoting co-ordination of work undertaken by the Organisation in the insurance field and for submitting opinions and proposals to the Council or to other Committees for this purpose.

To help it carry out this mandate, the Committee is assisted by a number of specialised working groups such as, at present, the Working Group on Insurance Statistics, the Ad Hoc Group on Insurance in Developing Countries and the Joint Working Group on Insurance Services of the Committee on Capital Movements and Invisible Transactions (CMIT) and of the Insurance Committee. The secretariat function for the Committee is performed by the Directorate for Financial, Fiscal and Enterprise Affairs and, more particularly, by its Financial Affairs Division.

\section{Activities of the Insurance Committee}

The activities of the Insurance Committee have spanned a period of almost 30 years. They have covered virtually every economic and regulatory aspect of the insurance markets 
in Member countries and have had a significant impact on the development of the insurance systems of Member countries and the regulatory setting within which they operate. ${ }^{2}$

The Insurance Committee has over the past few years increasingly developed its areas of work, which can be roughly classified around the following four activities: the liberalisation of insurance services and the development of insurance international co-operation, the gathering of information, the detailed analysis of markets and systems, and the development of relations with non-Member countries. The emphasis below will be on these recent or current activities.

\section{Liberalisation and co-operation}

Since its inception one of the main raisons d'être of the Insurance Committee has been to develop international co-operation in the insurance field and, above all, the liberalisation of the establishment and cross-border operations of insurance companies. This aim is being pursued in close co-operation with the Committee on Capital Movements and Invisible Transactions, which is the "watch-dog" for the two OECD Liberalisation Codes: the Code of Liberalisation of Current Invisible Operations and the Code of Liberalisation of Capital Movements.

The goal of these Codes is the elimination of restrictions on the conclusion and/or implementation of transactions or transfers relating to operations described therein and which, in the case of the Invisibles Code, concern most categories of services. Since the Codes have the legal force of a Council Decision, they are binding on all Member countries. However, the liberalisation that is called for need not necessarily be immediate - it can be gradual. In this respect, Member countries have the right to enter "reservations" to items in the Codes in accordance with very specific rules allowing them to maintain certain restrictions. These reservations are subject to regular review. Moreover, once they have been withdrawn, they cannot in principle be reinstated (this is known as the ratchet effect of the Codes). In addition, Member countries may request temporary dispensation from these obligations for specific economic reasons. ${ }^{3}$

One of the essential features of both Codes is that measures of liberalisation, as well as any restrictions, have to be applied to all countries without discrimination. Apart from one special OECD Decision dealing with specific reciprocity measures,${ }^{4}$ the Codes allow an exception, albeit a "positive" one, to this principle of non-discrimination: countries belonging to a special customs or monetary system (e. g. the European Economic Community) are permitted to apply to each other additional measures of liberalisation without extending them to other countries. This means that these countries may liberalise more rapidly or more widely among themselves; on the other hand, they may not raise new barriers to operations with third OECD countries.

2 For instance, at an early stage the Committee carried out pioneer work in respect of topical issues such as solvency margins and the concept of the policyholder's own initiative.

${ }^{3}$ As is the case in virtually all international agreements, restrictions can also be imposed in a more general way if they are deemed necessary to the maintenance of public order or the protection of a country's essential security interests.

4 The Organisation dealt with reciprocity issues by adopting a Decision in July 1986 , which applies exclusively to inward direct investment and establishment and under which reciprocity measures and practices are considered to have a somewhat different status from that of restrictions against which reservations can be lodged; but the procedures to be applied to them are essentially the same. 
Lastly, it is worth mentioning that the two Codes concern not only cross-border transactions but also freedom of international direct investment and freedom of establishment for non-resident investors. Another OECD instrument relating to national treatment concerns investment by enterprises under foreign control established in a host country and therefore also covers operations of this kind carried out by insurance companies.

The provisions of both Codes cover the insurance sector very comprehensively - in particular, an entire annex of the Code of Liberalisation of Current Invisible Operations is devoted to insurance. Member countries' reservations with regard to the insurance items in this Code are subject to regular reviews carried out jointly by the Insurance Committee and the Committee on Capital Movements and Invisible Transactions. The latest review (the sixth) is currently in progress and should result in a substantial withdrawal or scaling-down of reservations. In conjunction with this review, the Joint Working Group on Insurance Services, set up by these two Committees, is studying the provisions of the Code with a view to bringing these more into line with recent developments regarding trade in insurance services. A broad programme of work has been recently discussed in this regard. It will benefit in particular from the ongoing works undertaken by the Insurance Committee in areas such as obstacles to trade in insurance services, the role of insurance intermediairies or solvency issues. In addition, this Working Group is making substantial efforts to improve the transparency of the practices and administrative measures currently in force in the markets of Member countries.

These liberalisation efforts form part of a general policy of expanding co-operation in the insurance field that the Insurance Committee has been anxious to promote. As early as 1964 a Recommendation established a common classification of the classes of insurance and, in 1971, another Recommendation put forward suggestions as to formal methods of co-operation between supervisory authorities. So far these methods have not proved necessary, since the existing informal system of co-operation has proved more than adequate. Indeed, one of the other major benefits of the Committee's meetings is the scope for informal contacts. The opportunity for the supervisory authorities of the 24 Member countries to meet together in the OECD and address some delicate issues directly is of considerable value in promoting the genuine development of co-operation between Member countries.

In addition, the Committee's "plenary" discussions on co-operation and liberalisation provide the opportunity for frank and in-depth debates. In this respect, the OECD constitutes a particularly suitable forum, since its meetings are attended by representatives with a similar official or professional status of both governments and professional associations from what are currently the major geographic areas in terms of insurance.

\section{The gathering and exchange of information}

One of the first tasks to which the Insurance Committee devoted its attention was that of gathering information. The Working Group on Statistics collects detailed data on insurance premiums (gross and net) in Member countries. Premium business is broken down into direct business, reinsurance accepted and premiums ceded; national undertakings (separating out those under foreign control) and agencies and branches of foreign undertakings; the main categories of non-life insurance; business written within the country or abroad, for domestic or foreign risks, etc. A section dealing with investment has recently been incorporated in the questionnaire sent to Member countries. 
The information gathered is not only of a statistical nature: it also covers relevant laws and regulations, - as in the case of the Committee's report on the supervision of private insurance, known as the "Paratte Report" from the name of the Chairman of the Working Party which compiled the initial version in 1963. This report contains detailed information on the laws and regulations concerning the supervision of private insurance in Member countries. This compendium, which is currently being revised and updated, also serves as a very useful tool in connection with the technical assistance provided by the Committee to non-Member countries (see below).

Apart from its data-gathering function, the Committee provides, as already underlined, a unique forum for the exchange of information between representatives of the public and private sectors in North America, Europe and the Pacific. Currently, such information is of four types: topical items, detailed country data, information on other international bodies, and information on other OECD committees. On the basis of a document prepared by the Secretariat, delegates have the opportunity to discuss on topical insurance issues and on the positions adopted by government and supervisory bodies concerning them. They also regularly discuss reports prepared by Member country representatives on the recent evolution of their domestic markets (recent examples being France, Italy, the Netherlands, Portugal and Sweden). Likewise, representatives or participants in activities of other international bodies report on the work of these bodies in the insurance field - for example, the work of the EEC, the GATT, the Commission on Insurance of the International Chamber of Commerce, the International Conference of NAIC (US National Association of Insurance Commissioners) and the Conference of Insurance Supervisory Authorities of the EEC. In addition, the multidisciplinary character of the OECD permits a substantial exchange of information on the activities of other committees or groups (Environment Committee, Trade Committee, Financial Markets Committee, etc.) that are of interest to the Insurance Committee which, in turn, is frequently asked for its views. The Committee is increasingly aware of the need to encourage this exchange of information on an intersectoral as well as international basis and has accordingly established closer contacts with other sectoral committees within the Organisation.

\section{Analysis}

One of the more important recent developments in the Committee's work has been the launch of a number of new fields of investigation. The Committee's Secretariat has just completed a major study of the growing interrelationship between certain insurance services and other financial services. Following a comprehensive overview of the regulatory framework, the study goes on to analyse the factors underlying this process, the strategies adopted by the various concerned institutions and the changes that have occurred in the financial nature of insurance products. ${ }^{5}$

This report therefore meets one of the key OECD requirements for studies of this kind, namely to provide an analytical basis for formulating policies. In these analyses, government policymakers find a valuable source of comparative information for determining their policy and their attitude towards recent phenomena such as, for example, the link-ups between banking and insurance. It is well-known that these two sectors have characteristics

\footnotetext{
${ }^{5}$ Insurance and Other Financial Services: Structural Trends, OECD, Paris, 1992.
} 
of their own, meet specific demands, and play somewhat different economic, social and financial roles, which will continue to call for tailor-made regulatory settings. But as long as the attendant risks can be kept within acceptable bounds, convergence ought to make possible a more complementary, better-integrated approach to the management and sale of certain financial services, which should benefit both the providers and the consumers of those services. Governments are aware of this, and are doing their best to bring in new regulations, allowing convergence when necessary and at the same time controlling it. The comparative analysis provided by such a report is intended to contribute to help them to succeed in this difficult task.

Other major studies are currently being carried out. For example, a special analysis has been undertaken on the new role of insurance intermediaries. Their role has recently been affected by a whole series of factors whose effects need to be assessed, such as the internationalisation of trade in insurance services, the development of financial integration, the cross-sectoral distribution of insurance products through financial networks and of financial products through insurance networks, customers' growing demands for full financial information, fierce competition within the financial world, the development of new products, the creation of a single European market, the impact of new communication and data processing technologies, etc. Another key project in this area is the updating of the 1983 report on the identification and analysis of obstacles to international trade in insurance services (in the broadest sense, including direct investment), with the aim of assessing the most important impediments, practical as well as regulatory, that remain within the OECD area. The question of insurers' solvency is also being addressed. This embraces in particular the implications of the creation of financial conglomerates, the marketing of financial products by insurers and companies' investment policies. These factors, together with the recent problems encountered by some insurers in this respect, have given rise to renewed concern among policymakers about the availability of adequate systems for enforcing solvency requirements. Other projects (generally on regulatory systems and supervision but also in specific areas such as contracts laws) have been launched in relation to the Committee's work on Central and Eastern European countries (see below).

The Insurance Committee also contributes to work initiated by other committees, such as the studies by the Trade Committee on the relevance to the insurance sector of the conceptual framework for trade in services and on insurance in the developing countries, the study by the Consumer Policy Committee on life insurance (1987), the study by the Accounting Standards Group on the operating results of insurance companies (1988), the study by the Road Transport Research Co-operation Programme on road accident prevention (1990), the Environment Committee's report on pollution insurance and compensation funds (1991), etc.

\section{Relations with non-Member countries}

The Insurance Committee already deals with matters relating to certain non-Member countries through its Ad Hoc Working Group on Insurance in Developing Countries. This Group, which meets periodically, has discussed reports submitted by a number of Member countries as well as reports prepared by another OECD Committee, the Trade Committee. The intention is that the Insurance Committee should, in the future, be involved in the Organisation's work and contacts with certain Latin American and Asian countries, several 
of which have seen substantial growth in their insurance sector. At present, however, the Insurance Committee's focus is on the expansion of its activities and its contacts primarily with another set of non-member countries, those of Central and Eastern Europe.

In March 1990 the OECD Council decided to set up the Centre for Co-operation with the European Economies in Transition, responsible for:

- designing and managing the OECD programme of activities, carried out by the Organisation's different specialised Directorates, in support of economic reforms in Central and Eastern Europe;

- providing the focal point for all the OECD's contacts with these countries and access to OECD expertise; involving experts from Member countries, the business sector and the labour unions in the OECD's assistance activities;

- maintaining contacts with other international organisations working in the same field, to ensure effective collaboration;

- offering a certain amount of training in some specialised fields to officials from the reforming countries.

The Centre's activities can be divided into two main groups: the Centre's regular programme of activities open to all "CEEC" countries (i.e. currently: the Baltic States, Bulgaria, the Czech and Slovac Federal Republic, Hungary, Poland, Roumania and the "C.I.S.") and the "Partners in Transition" programme, which concerns the Czech and Slovac Federal Republic, Hungary, and Poland.

The Insurance Committee has embarked upon a series of activities in connection with these two programmes with the aim of achieving the broadest possible degree of operational effectiveness. Thus, it is planned to organise a workshop involving the Committee's experts and representatives of all the countries concerned. So far, however, most of the work has focused on the three countries covered by the Partners in Transition programme. In February 1991, for example, a preliminary informal meeting was held between OECD experts and representatives of the insurance supervisory authorities in Hungary to discuss the terms of a draft law for insurance in that country. A similar meeting was held in October 1991 with Czech and Slovac representatives. This meeting provided the opportunity for an assessment of the two parallel legal systems currently in force in the Republic, a substantial exchange of information and the outlining of a plan for future co-operation in the insurance area between this country and the OECD. ${ }^{6}$ In this connection it should be stressed that these meetings are certainly not intended to supply these countries with a single, standard recipe but rather with a range of possibilities and appropriate advice. The main raison d'être of these meetings and the contacts they give rise to is to provide an effective response to the needs that these countries have themselves identified in the insurance area. At present, these mainly cover the legislative aspects, supervision, solvency, contract law, investment policy, etc. Some specific studies have been launched in this respect.

The Insurance Committee, through the technical assistance it is able to provide, is thus helping the Central and Eastern European countries in their transition to a market economy. This work is being closely co-ordinated with that of other bodies, such as the

\footnotetext{
${ }^{6}$ Another meeting was also recently held in Warsaw with Polish representatives (February 1992).
} 
EEC Commission, so as to avoid duplication. It goes without saying that, by virtue of the structure of the OECD, the aid that it provides is in the form of technical assistance targeted at senior officials in the countries concerned rather than financial aid or training programmes as such.

There is bound to be a steady expansion of insurance activities within the OECD, given the recent evolution, not to say revolution, that has occurred in the international and intersectoral dynamic of the insurance markets in Member countries, from a regulatory as well as a business standpoint. The Insurance Committee can therefore be expected to develop further the four areas of activity described above in order to ensure :

- greater availability of policy-related information of an international character through the gathering of regulatory and statistical data and comparative analyses;

- increased assistance in the form of the high-level technical aid it provides to other less experienced countries;

- and, most importantly, closer co-operation particularly through its work on liberalisation issues and contacts between supervisory authorities. 